\title{
TINGKAT KESESUAIAN SOAL TEORI UJI KOMPETENSI KEAHLIAN TEKNIK GAMBAR BANGUNAN DENGAN STANDAR KOMPETENSI NASIONAL BIDANG GAMBAR BANGUNAN
}

\author{
Abdul Malik \\ Pendidikan Teknik Sipil dan Perencanaan, FT, UNY \\ E-mail: abdul.malik@uny.ac.id
}

\begin{abstract}
Phenomena that show the competence of building drawings that are needed in the world of work but have not been studied in schools are the basis of research. It is necessary to measure the level of compatability between the materials being studied with the competencies required by the world of work. The purpose of this study was to determine the suitability level of the content of the skills competency test (UKK) based on the National Competency Standars in the Building Drawing Field. The research method used is comparative descriptive. The subject of this research is the matter of the theory of UKK Building Drawing Engineering. Data were analyzed by comparing the level of competency suitability implemented in the UKK theory problem with the National Competency Standards in Building Drawing Field. The results of the study showed that in the implementation of the UKK Building Drawing Tecnique in theory there were 37 competencies tested. Total competencies at the level of young photographers for vocational graduates are 55 competencies. There are 18 competencies that have not been tested on UKK, so there needs to be an adjustment so that the UKK content goes hand in hand with the work competencies required for building drawing skills.
\end{abstract}

Keywords: expertise competency test, building drawing

\begin{abstract}
ABSTRAK
Fenomena menunjukkan adanya kompetensi gambar bangunan yang diperlukan di dunia kerja tetapi belum dipelajari di Sekolah menjadi dasar dalam pengkajian. Perlu adanya pengukuran tingkat kesesuaian antara materi yang dipelajari dengan kompetensi yang disyaratkan dunia kerja. Tujuan dari pengkajian ini adalah mengetahui tingkat kesesuaian antara konten soal Uji Kompetensi Keahlian (UKK) mengacu pada Standar Kompetensi Nasional Bidang Gambar Bangunan. Metode pengkajian yang digunakan adalah deskriptif komparatif. Subjek pada pengkajian ini adalah soal teori UKK Teknik Gambar Bangunan. Data dianalisis dengan membandingkan antara tingkat kesesuaian kompetensi yang dilaksanakan dalam soal teori UKK dengan Standar Kompetensi Nasional Bidang Gambar Bangunan. Hasil pengkajian menunjukkan dalam pelaksanaan UKK Teknik Gambar Bangunan secara teori terdapat 37 kompetensi yang diujikan. Total kompetensi pada level juru gambar muda untuk lulus SMK adalah 55 kompetensi. Terdapat 18 kompetensi yang belum diujikan pada UKK, sehingga perlu adanya penyesuaian agar konten UKK beriringan dengan kompetensi kerja yang disyaratkan pada keahlian gambar bangunan.
\end{abstract}

Kata Kunci: Uji Kompetensi Keahlian, gambar bangunan

\section{PENDAHULUAN}

Dapat dilihat dari banyaknya perubahan yang terjadi pada saat ini memperlihatkan suatu zaman yang semakin berkembang. Perlu dilakukan penataan terhadap sistem pendidikan secara menyeluruh, terutama berkaitan dengan kualitas pendidikan serta kesesuaian dengan kebutuhan Dunia kerja yang sesuai dengan realita. Hal ini, perlu adanya perubahan sosial yaitu perubahan dari pandangan kehidupan masyarakat lokal ke masyarakat global, perubahan dari kohesi sosial menjadi partisipasi demokratis, dan perubahan dari pertumbuhan ekonomi ke perkembangan kemanusiaan yang memberi arah bahwa pendidikan merupakan pendekatan mendasar dalam proses perubahan itu (Mulyasa, 2013). 
Menurut Dikti tahun 2011, Diskriptor setiap jenjang kualifikasi KKNI yang merupakan perpaduan antara kompetensi yang dibutuhkan dunia kerja dan ketercapaian pembelajaran yang disesuaikan dengan perkembangan ilmu pengetahuan, teknologi, dan seni perkembangan sektor-sektor pendukung perekonomian kesejahteraan rakyat seperti perindustrian, pertanian, kesehatan, hukum dan aspek lain yang terkait, serta aspekaspek pembangun jati diri bangsa yang tercermin dalam bhineka tunggal ika, yaitu komitmen untuk tetap mengakui keragaman agama, suku, budaya, bahasa dan seni yang tumbuh dan berkembang di bumi Indonesia.

Kompetensi menjadi salah satu permasalah yang dihadapi SMK (Astikasari, 2015). Bisa dilihat bahwasanya masih ada kurang keselarasan, antara kompetensi yang diperlukan di dunia kerja denga kompetensi yang sampaikan di SMK. Sementara dunia kerja kurang optimal dalam menyerap tenaga kerja tamatan SMK, dan lebih berminat menggunakan tenaga kerja yang sudah berpengalaman, sehingga tenaga kerja tamatan SMK yang belum memiliki kompetensi optimal sesuai kebutuhan Dunia kerja pada akhirnya tidak memperoleh peluang kerja dan malah menjadi pengangguran.

Semakin berkembangnya ilmu pengetahuan dan teknologi yang berlangsung cepat dalam era revolusi industri ini, turut mempengaruhi terhadap perkembangan dunia kerja. Semakin berkembangnya ilmu pengetahuan dan teknologi, maka kualifikasi tenaga kerja yang dibutuhkan dunia kerja juga ikut meningkat. Tenaga kerja dituntut memiliki kompetensi yang sesuai dengan tuntutan kebutuhan dunia kerja. Tenaga kerja merupakan seseorang yang mampu melakukan kegiatan pekerjaan guna menghasilkan barang dan jasa baik untuk memenuhi kebutuhan diri pribadi maupun masyarakat global.

Pada saat sekarang ini pengalaman kerja sangat diperlukan, seperti yang diungkapkan (Sutomo, dkk,1999) pada saat ini dunia kerja mencari pekerjanya lebih mengutamakan tenaga kerja yang telah memiliki pengalaman dibidang pekerjaan tersebut. Dengan mendapatkan pekerja yang sudah memiliki pengalaman, lebih mempermudah dunia kerja menyelesaikan pekerjaannya. Selain itu, pengalaman kerja menggambarkan pengetahuan pasar kerja. Dengan memiliki pengalaman kerja didukung tingkat pendidikan yang tinggi, maka tenaga kerja akan mempunyai lebih banyak kesempatan untuk mendapatkan pekerjaan (Satrio Adi, 2010).

Ketidaksesuaian antara Dunia kerja dengan dunia pendidikan kejuruan ini perlu diukur tingkat keselarasannya dengan dilakukan pengontrolan dan penyeimbang, sebagai upaya untuk mengontrol dan menyeimbangkan kompetensi antara Dunia kerja dengan dunia pendidikan maka dilaksanakan Uji Kompetensi Keahlian (UKK) baik secara teori maupun secara praktik. Dengan adanya uji kompetensi, yang melibatkan daripada pihak Dunia kerja dapat menilai kompetensi yang diperoleh siswa di sekolah, yang sesuai maupun yang tidak dibutuhkan di Dunia kerja. Dalam Hal konten yang menjadi alat uji menjadi dasar perlu adanya penyesuaian dengan Dunia kerja. Uji kompetensi diperlukan untuk mengetahui kemampuan atau keahlian (kompetensi) seseorang sesuai dengan standar profesi (Irwanti, 2014).

Uji kompetensi adalah proses penilaian, baik teknis maupun nonteknis, melalui pengumpulan bukti yang relevan untuk menentukan apakah seseorang kompeten atau belum kompeten pada suatu unit kompetensi atau kualifikasi tertentu (Abdurahman, 2015) Proses pembelajaran di SMK pada akhir kegiatan akan dilaksanakan evaluasi kompetensi keahlian yang bertujuan untuk mengetahui apakah siswa sudah memenuhi kompetensi ataukah belum yang ditinjau dari Dunia kerja. Uji kompetensi keahlian (UKK) bagi siswa SMK terdiri dari uji kompetensi 
keahlian teori dan uji kompetensi keahlian praktik, ujian ini bertujuan untuk mengukur pencapaian kompetensi siswa pada level tertentu sesuai dengan kompetensi keahlian yang mereka tempuh selama mengikuti pendidikan di SMK (direktorat PSMK, 2017).

Tujuan dari pelaksanaan UKK antara lain bertujuan untuk 1) mengukur pencapain kompetensi siswa SMK yang akan menyelesaikan pendidikannya, 2) memfasilitasi siswa SMK yang akan menyelesaikan pendidikannya untuk mendapatkan sertifikat kompetensi, 3) mengoptimalkan pelaksanaan sertifikasi kompetensi oleh SMK yang berorientasi pada permintaan industri terhadap tenaga kerja kompeten yang memiliki sertifikat kompetensi, 4) memfasilitasi kerjasama SMK dengan Dunia kerja dalam rangka memenuhi kebutuhan tenaga kerja kompeten bersertifikat kompetensi. Dalam pelaksanaannya, sebelum dilaksanakan UKK diadakan dulu verifikasi yang melibatkan unsur Dunia kerja. UKK bertujuan untuk mengukur pencapaian kompetensi siswa pada level tertentu sesuai kompetensi keahlian yang ditempuh di SMK (BNSP, 2017).

Keberhasilan pendidikan kejuruan tidak hanya dilihat dari banyaknya lulusan yang dihasilkan akan tetapi lebih dilihat dari penampilan (performance) atau kecakapan lulusan dalam dunia kerja. Diungkapkan oleh (Sukamto, 1988) bahwa keberhasilan belajar yang berupa kelulusan dari sekolah kejuruan adalah tujuan terminal, sedangkan keberhasilan program secara tuntas berorientasi kepada penampilan para lulusannya kelak di lapangan kerja.

Diperlukan peran pendidik kejuruan yang berperan aktif dalam merancang metode pengembangan pembelajaran baik di dalam kelas maupun di luar kelas yang dapat mengembangkan metakognitif siswa. Guru sekolah menengah kejuruan harus terus mengidentifikasi dan mengupgrade kompetensi mereka (Jaewoo \& Woonsun, 2014). Cara-cara untuk membantu siswa sekolah menengah kejuruan mengembangkan sikap positif, motivasi intrisik dan ekstrinsik adalah dengan menanamkan keyakinan bahwa belajar merupakan hal yang mereka harus lakukan terus menerus sepanjang hayat.

Tenaga kerja lulusan SMK merupakan tenaga kerja tingkat menengah setingkat teknisi. Lulusan SMK khususnya bidang keahlian teknik gambar bangunan dapat memasuki dunia kerja yang berhubungan dengan menggambar bangunan (Drafter). Lulusan SMK dapat bekerja pada $\mathrm{cv}$ dan atau perusahaan bidang konstruksi bangunan. Jenis pekerjaan lulusan SMK teknik gambar bangunan dapat bekerja sebagai perencana bangunan, pelaksana bangunan, pengawas bangunan yang semua itu harus memiliki keahlian menggambar bangunan (Drafter).

Kompetensi merupakan kata kunci dari proses pendidikan terutama untuk sekolah kejuruan. Kompetensi merupakan pengetahuan, keterampilan, sikap dan nilai-nilai yang diwujudkan dalam kebiasaan berpikir dan bertindak. Depdiknas mengartikan kompetensi sebagai kemampuan seseorang yang disyaratkan untuk menyelesaikan pekerjaan tertentu pada dunia kerja dan ada pengakuan resmi atas kemampuan tersebut (Riana T.Mangesa, 2009).

Dalam hal ini kompetensi dapat divisualisasikan dari dua makna dasar, yang pertama pengetahuan, keterampilan dan sikap yang memungkinkan bisa di artikan sebagai pengambilan keputusan yang tepat dalam setiap kasus dan keputusan dalam suatu situasi. Kedua meliputi karakteristik dan kualitas individu untuk melaksanakan kegiatan efektif yang menjelaskan nilai tambah profesional kedalam praktik dan hasil (Eulalia Juve, 2007). Dorongan pendidikan berbasis kompetensi telah dianjurkan dalam pendidikan. Transformasi pendidikan dan pelatihan berdasarkan kompetensi dasar yang diperlukan, perlu untuk sebagai dasar persyaratan (Struyven \& De 
Meyst, 2010). Kompetensi lebih menekankan pada standar keterampilan, yang harus dimiliki siswa (Thorkildsen \& Raholm, 2010).

Kompetensi di sekolah yaitu kompetensi dasar yang merupakan sejumlah kemampuan yang harus dikuasai peserta didik dalam mata pelajaran tertentu sebagai rujukan dalam penyusunan indikator kompetensi dalam suatu pelajaran (Suyatno, 2009). Sedangkan kompetensi dunia kerja adalah kemampuan yang dimiliki seseorang untuk dapat bersaing dan mengembangkan perusahaan sesuai apa yang disyaratkan dan dengan standar yang telah disepakati. (Judisusseno, 2008) mengungkapkan jenis kompetensi yang diharapkan di dunia kerja digolongkan menjadi 4 kategori yaitu: (a) pengetahuan (knowledge), (b) keterampilan (skill), (c) sikap (attitude), dan (d) lain-lain (others).

Bidang gambar bangunan tidak bisa dilepaskan dari dunia usaha jasa konstruksi. Usaha jasa konstruksi sendiri dapat diartikan sebagai bidang usaha jasa pengadaan bangunan (gedung, jalan, bendungan, dan lain-lain). Jasa pengadaan bangunan sendiri melewati suatu proses yang dapat diurutkan secara garis besar sebagai berikut.

1. Tahap perencanaan/perancangan, pada tahap ini bangunan yang akan dibuat dimodelkan dalam suatu bentuk 2 dimensi (gambar) atau 3 dimensi (maket) disertai dengan berbagai dokumen tertulis sebagai pendukung
(Rencana Anggaran Biaya/ RAB, spesifikasi teknis dan lain-lain). Keseluruhan dokumen ini, disebut sebagai dokumen perencanaan, akan dijadikan sebagai acuan bagi tahap selanjutnya.

2. Tahap asembling/ perakitan, tahap ini merupakan tahap pilihan yang tidak selalu dilaksanakan, tergantung dari kondisi proyek. Perakitan merupakan pekerjaan konstruksi skala kecil pada elemen bangunan seperti kuda-kuda baja, elemen pracetak, dan lain-lain. Tahap ini bisa dilaksanakan di lapangan atau di lokasi workshop/ pabrik.

3. Tahap konstruksi, tahap ini merupakan tahap akhir pembuatan bangunan di lapangan. Tahap ini dilaksanakan dengan acuan dokumen perencanaan.

Jenjang kualifikasi juru gambar/ drafter di dalam dunia industri konstruksi terutama di kalangan konsultan masih sangat beragam. Keberagaman jenjang kenaikan jabatan ini disebabkan oleh banyak faktor, dan yang paling utama adalah perbedaan struktur organisasi dari masing-masing konsultan. Disamping itu penamaan dari jabatan-jabatan tersebut juga cukup beragam, bahkan deskripsi kerjanya juga relatif beragam, bahkan terkadang masuk ke jalur yang lain, seperti quantity surveyor atau engineer. Salah satu jenjang kualifikasi yang banyak ditemukan di dalam dunia profesi juru gambar dapat dilihat pada tabel 1 berikut ini (Raharjo, 2003). 
Tabel 1. Hubungan Antara Jenjang Kualifikasi Dengan Jenjang Pendidikan

\begin{tabular}{|c|c|c|c|}
\hline $\begin{array}{l}\text { Jenjang } \\
\text { Kualifikasi } \\
\text { Pola } 1\end{array}$ & $\begin{array}{l}\text { Jenjang } \\
\text { Kualifikasi } \\
\quad \text { Pola } 2\end{array}$ & $\begin{array}{c}\text { Jenjang } \\
\text { Pendidikan }\end{array}$ & Keterangan \\
\hline & Trainee Drafter & \multirow{2}{*}{ UMUM } & \multirow{2}{*}{$\begin{array}{l}\text { Yang dibutuhkan jenjang ini adalah kemampuan } \\
\text { pemakaian peralatan manual maupun komputer } \\
\text { beserta perangkat lunak menggambar teknik. }\end{array}$} \\
\hline & Tracer Drafter & & \\
\hline $\begin{array}{l}\text { Juru Gambar } \\
\text { Muda }\end{array}$ & $\begin{array}{l}\text { Juru Gambar } \\
\text { Detail Junior }\end{array}$ & SMK & $\begin{array}{l}\text { Jenjang ini memerlukan pengetahuan konstruksi } \\
\text { bangunan untuk memudahkan dan mempercepat } \\
\text { penyelesaian tugas. }\end{array}$ \\
\hline $\begin{array}{l}\text { Juru Gambar } \\
\text { Senior }\end{array}$ & $\begin{array}{l}\text { Juru Gambar } \\
\text { Detail Senior }\end{array}$ & D3 & $\begin{array}{l}\text { Jenjang ini memerlukan pengetahuan konstruksi } \\
\text { bangunan yang lebih tinggi disertai pemahaman } \\
\text { prinsip-prinsip disiplin ilmu lain untuk } \\
\text { memudahkan dan mempercepat penyelesaian } \\
\text { tugas. Kemampuan manajerial terbatas } \\
\text { diperlukan untuk mengkoordinir pekerjaan } \\
\text { bawahan. }\end{array}$ \\
\hline $\begin{array}{l}\text { Juru Gambar } \\
\text { Kepala }\end{array}$ & $\begin{array}{l}\text { Juru Gambar } \\
\text { Kepala }\end{array}$ & D4 & $\begin{array}{l}\text { Kemampuan manajerial diperlukan dalam } \\
\text { pengelolaan suatu proyek yang melibatkan } \\
\text { berbagai disiplin ilmu lain. }\end{array}$ \\
\hline $\begin{array}{l}\text { Juru Gambar } \\
\text { Desain }\end{array}$ & $\begin{array}{l}\text { Juru Gambar } \\
\text { Desain }\end{array}$ & \multirow[t]{2}{*}{ S1 } & $\begin{array}{l}\text { Kemampuan pengembangan desain, di samping } \\
\text { pengetahuan teknik dan koordinasi berbagai } \\
\text { disiplin ilmu diperlukan untuk mengembangkan } \\
\text { gagasan arsitek atau engineer. }\end{array}$ \\
\hline Kepala Studio & Kepala Studio & & $\begin{array}{l}\text { Kemampuan manajerial diperlukan dalam } \\
\text { pengelolaan berbagai proyek dalam suatu studio } \\
\text { gambar. }\end{array}$ \\
\hline
\end{tabular}

Kegunaan dari kajian ini diharapkan dapat mengetahui tingkat kesesuaian antara konten soal uji kompetensi keahlian (UKK) dengan mengacu pada standar kompetensi Nasional Bidang Gambar Bangunan (SKKNI) sehingga dapat mengambil kebijakan untuk menyesuaikan materi yang diajarkan sehingga menjadi dasar kompetensi yang perlu dimiliki siswa. sehingga lulusan teknik gambar bangunan memenuhi kualifikasi SKKNI

\section{METODE}

Pengkajian ini merupakan jenis pengkajian deskriptif komparatif non hipotesis (tanpa hipotesis) dengan pendekatan kualitatif. menggambarkan semua data atau keadaan subyek/obyek pengkajian (seseorang, lembaga, masyarakat dan lain-lain) kemudian dianalisis dan dibandingkan berdasarkan kenyataan yang sedang berlangsung pada saat ini dan selanjutnya mencoba untuk memberikan pemecahan masalah.

Pengkajian deskriptif komaparatif non hipotesis (tanpa hipotesis) dengan pendekatan kualitatif dipilih karena bermaksud menyajikan data secara sistematis, faktual, dan akurat mengenai fakta-fakta tentang kesesuaian UKK Teknik Gambar Bangunan dengan kebutuhan

Dunia kerja yang akan dideskripsikan dengan cara menganalisis alat uji yaitu dalam hal ini soal uji kompetensi teori yang nantinya di sesuaikan dengan Kebutuhan Dunia kerja Melalui Standar Kompetensi Nasional Bidang Gambar Bangunan. 
Dalam hal ini, objek merupakan hal yang menjadi titik perhatian dari suatu pengkajian. Adapun objek pengkajian dalam tulisan ini adalah konten UKK Teknik Gambar Bangunan lebih tepatnya pada soal yang diujikan dalam pelaksanaan UKK Sejalan dengan hal tersebut maka instrumen yang digunakan dalam pengkajian ini adalah lembar analisis kesesuaian soal uji kompetensi keahlian Teknik Gamba Banguna dengan Kebutuhan Dunia kerja yang diteliti, lembar observasi yang dijadikan sumber pengkajian adalah soal UKK teori berdasarkan Standar Kompetensi Nasional Bidang Gambar Bangunan.

\section{HASIL DAN PEMBAHASAN}

Ada beberapa hal yang erat kaitannya antara UKK dengan kebutuhan Dunia kerja, dalam hal ini pengkajian yang dilaksanakan adalah terpenuhinya kompetensi siswa SMK Teknik Gambar Bangunan pada level SMK atau dapat di katakan masuk kepada jenjang kualifikasi tingkat juru gambar muda atau juru gambar detail junior. Jenjang ini memerlukan pengetahuan kontruksi bangunan untuk memudahkan dan mempercepat penyelesaian tugas. Dalam hal ini jenjang juru gambar muda atau juru gambar detail juior sudah melewati tahap Trainee Drafter dan Tracer Drafter yang mana jenjang ini adalah kemampuan umum yang perlu di kuasai, dalam hal ini kemapuan pemakaian peralatan manual maupun komputer/digital beserta perangkat lunak menggambar teknik. Dalam hal ini pembahasan dibagi kedalam dua bagian yaitu UKK Teori.

Berdasarkan pengamatan dokumen yang dilakukan pada Pelaksanaan Uji Kompetensi Keahlian Teknik Gambar Bangunan SMK Negeri Rajapolah diketahui bahwa pelaksanaan UKK Teknik Gambar Bangunan yang diterapkan saat ini yaitu mengacu kepada Pedoman Pelaksanaan UKK. Hal ini disebabkan terlaksananya UKK. Pada pealksanaan pengambilan data di dapatkan data soal UKK teori. Dalam hal ini yang digunakan pembanding dengan dunia kerja adalah Standar Kompetensi Nasional Bidang Gambar Bangunan.

Berdasarkan pengkajian yang dilakukan adannya banyak unit kompetensi dengan kualifikasinya yang sesuai di Dunia kerja dilihat melalui Standar Kompetensi Nasional Bidang Gambar Bangunan. Jenjang yang di capai dalam hal ini adalah jenjang kualifikasi juru gambar muda atau detail junior yang seharusanya dapat diisi oleh lulusan SMK karena menuntut keterampilan penggunaan alat manual atau digital dan pengetahuan kontruksi yang umum digunakan. Tabel 2 hasil penyesuaian antara UKK Teori Keahlian Teknik Gamabar Bangunan dan Dunia kerja berdasarkan Standar Kompetensi Nasional Bidang Gambar Bangunan.

Tabel 2. Daftar Kompetensi UKK Teori berdasarkan Standar Kompetensi Nasional Bidang Gambar Bangunan

\begin{tabular}{|c|c|}
\hline No & Unit Kompetensi \\
\hline 1 & Menggambar Garis Tegak Lurus dan Garis Sejajar \\
\hline 2 & Membagi Garis \\
\hline 3 & Menggambar Sudut \\
\hline 4 & Menggambar Segitiga \\
\hline 5 & Menggambar Lingkaran \\
\hline 6 & Menggambar Segilima Beraturan \\
\hline 7 & Menggambar Segienam Beraturan \\
\hline 8 & Menggambar Segitujuh Beraturan \\
\hline
\end{tabular}




\begin{tabular}{|c|c|}
\hline No & Unit Kompetensi \\
\hline 9 & Menggambar Segidelapan Beraturan \\
\hline 10 & Menggambar Isometri Kubus \\
\hline 11 & Menggambar Proyeksi Orthogonal \\
\hline 12 & Melakukan back up data level $1(*)$ \\
\hline 13 & Melakukan restore data level $1(*)$ \\
\hline 14 & Mengelola File dan Folder pada Sistem Operasi \\
\hline 15 & Menggambar Dasar dengan Perangkat Lunak untuk Menggambar Teknik \\
\hline 16 & $\begin{array}{l}\text { Mengatur Tata Letak Gambar pada Model Space dengan Perangkat Lunak untuk } \\
\text { Menggambar Teknik }\end{array}$ \\
\hline 17 & Menggambar Proyeksi Bangunan \\
\hline 18 & Mencetak Gambar dengan Perangkat Lunak untuk Menggambar Teknik \\
\hline 19 & Menggambar Konstruksi Lantai dari Keramik/ Ubin/ Parket \\
\hline 20 & Menggambar Konstruksi Bata/ Batako \\
\hline 21 & Menggambar Rencana Kusen dan Daun Pintu/ Jendela dari Kayu \\
\hline 22 & Menggambar Rencana Kusen dan Daun Pintu/ Jendela dari Aluminium \\
\hline 23 & Menggambar Konstruksi Finishing Tangga dari Beton \\
\hline 24 & Menggambar Konstruksi Tangga dan Railing dari Kayu \\
\hline 25 & Menggambar Konstruksi Tangga dan Railing dari Besi/ Baja \\
\hline 26 & Menggambar Konstruksi Langit-Langit Konvensional \\
\hline 27 & Menggambar Konstruksi Penutup Atap dari Genteng, Sirap dan Asbes \\
\hline 28 & Menggambar Konstruksi Pondasi Dangkal dari Batu Kali atau Rollaag dari Bata/ Batako \\
\hline 29 & Menggambar Konstruksi Pondasi Dangkal Telapak dari Beton Bertulang \\
\hline 30 & Menggambar Rencana Pelat Lantai \\
\hline 31 & Menggambar Rencana Penulangan Tangga dari Beton Bertulang \\
\hline 32 & Menggambar Rencana Balok dan Kolom dari Beton Bertulang \\
\hline 33 & Menggambar Konstruksi Rangka Atap Sistem Kuda-Kuda dari Kayu \\
\hline 34 & Membuat Gambar Catatan dan Legenda Umum \\
\hline 35 & Menggambar Lembar Halaman Muka dan Informasinya \\
\hline 36 & Mengatur Tata Letak Gambar Manual \\
\hline 37 & Menggambar Lanjut dengan Perangkat Lunak untuk Menggambar Teknik \\
\hline
\end{tabular}

Pengkajian yang dilakukan memperoleh data kompetensi yang diujikan dalam UKK. Data kompetensi yang diperoleh kemudian dibandingkan dengan data kompetensi yang ada pada Dunia kerja berdasarkan Standar Kompetensi Nasional Bidang Gambar Bangunan. Berdasarkan data yang diperoleh, diketahui bahwa jumlah unit 
kompetensi yang ada pada Standar Kompetensi Nasional, yang sesuai dengan kualifikasi lulusan SMK ada 55 unit kompetensi yang di perlukan. Dalam pelaksanaan UKK Teori memeperoleh data kesesuaian dengan Dunia kerja berdasarkan Standar Kompetensi Nasional Bidang Gambar Bangunan ada 37 unit kompetensi. Sedangkan yang tidak ada dalam
UKK Teori ada 18 unit kompetensi yang tidak terujikan. Terdapat pula dalam UKK Teori Teknik Gambar Bangunan tetapi tidak termasuk untuk pengujian kualifikasi lulusan SMK menurut Dunia kerja berdasarkan Standar Kompetensi Nasional Bidang Gambar Bangunan.

Tabel 3. Rekapitulasi Hasil Kesesuaian Unit kompetensi

\begin{tabular}{|c|c|c|}
\hline No & Keterangan & $\begin{array}{l}\text { Jumlah Unit } \\
\text { Kompetensi }\end{array}$ \\
\hline 1 & $\begin{array}{l}\text { Total Unit Kompetensi Menurut Standar Kompetensi Keahlian } \\
\text { Bidang Gambar Bangunan jenjang kualifikasi juru gambar muda/ } \\
\text { juru gambar detail junior }\end{array}$ & 55 \\
\hline 2 & Total unit Kompetensi yang di Ujikan dalam UKK Teori & 37 \\
\hline 3 & Total unit Kompetensi yang tidak di Ujikan dalam UKK Teori & 18 \\
\hline
\end{tabular}

Dalam pelaksanaan UKK teknik gambar Bangunan yang terselenggarakan masih ada beberapa unit kompetensi yang seharusnya terujikan tetapi tidak dapat terujikan. Dari pelaksanaan UKK secara teori

\section{SIMPULAN}

Pengkajian ini hanya sebatas mengukur seberapa jauh tingkat soal yang di ujikan dalam UKK dengan kebutuhan dunia kerja yang berdasarkan Standar Nasional Bidang Gambar Bangunan. Soal UKK teori teknik gambar bangunan ditinjau berdasarkan ada beberapa yang belum terujikan. untuk UKK teori ada 18 unit kompetensi yang belum terujikan yang menjadi salah satu kompetensi yang seharusnya dimiliki seorang juru gambar muda.

Standar Kompetensi Nasional Bidang Gambar Bangunan untuk menjadi seorang juru gambar muda, dari 55 unit kompetensi yang perlu di kuasai sebagai seorang juru gambar muda baru 37 unit kompetensi yang terujikan masih ada sekitar 18 unit kompetensi yang masih belum terujikan dalam UKK secara teori.

\section{DAFTAR RUJUKAN}

Abdurrahman 2015 Upaya Mengurangi Kelelahan dalam Uji Kompetensi Keahlian Otomotif di Sekolah Menengah

Kejuruan dengan Uji Model Tidak Kontinyu. Jurnal Pendidikan dan Kebudayaan, Vol. 21

http://jurnaldikbud.kemdikbud.go.id/inde x.php/jpnk/article/view/176/158

Astikasari Yogi 2015 Tingkat Kesesuaian Kompetensi Mata Pelajaran Gambar Bangunan Paket Keahlian Teknik Gambar Bangunan SMK Negeri 2 Depok dengan Kebutuhan Dunia Kerja di Yogyakarta, Skripsi Pendidikan Teknik 
Sipil dan Perencanaan, Fakultas Teknik, Universitas Negeri Yogyakarat https://eprints.uny.ac.id/21661/1/Yogi\%2 0Astikasari\%2012505247002.pdf

BNSP. 2017. Pedoman Penyelengaraan Uji Kompetensi Keahlian SMK. Jakarta: Direktorat Jendral Pendidikan Menengah Kementrian Pendidikan dan Kebudayaan.

Dikti. 2011. Kerangka Kualifikasi nasional Indonesia (IQF) kajian tentang implikasi dan strategi implementasi KKNI Jakarta: Kementrian Pendidikan Nasional.

Direktorat Pembinaan Sekolah Menengah Kejuruan dan Direktorat Jendral Pendidikan Dasar dan Menengah. 2017. Pedoman Penyelenggaraan UJI KOMPETENSI KEAHLIAN Tahun Pelajaran 2016/2017. Jakarta: Kementrian Pendidikan dan Kebudayaan.

Eulàlia Juvé, M., Huguet, M., Monterde, D., José Sanmartín, M., Martí, N., Cuevas, B., ... Alvarez, G. 2007. Marco teórico y conceptual para la definición y evaluación de competencias del profesional de enfermería en el ámbito hospitalario. Parte I. Nursing (Ed. Española), 25(4), 56-61. https://doi.org/10.1016/S02125382(07)70907-X

Irwanti, Y.D. Evaluasi Uji Kompetensi Siswa Keahlian Multimedia di SMK se-Kota Yogyakarta. Jurnal Pendidikan Vokasi Vol.4 nomor 3 420-433 http://journal.uny.ac.id/index.php/jpv/arti cle/view/- 2564

Jaewoo, C., \& Woonsun, K. 2014. Korean Vocational Secondary School Students' Metacognition and Lifelong Learning. Procedia - Social and Behavioral Sciences $\quad 116 \quad 3519-3523$. https://doi.org/10.1016/j.sbspro.2014.01. 796
Judisseno, Rimsky K 2008. Jadilah Pribadi Yang Kompeten di Tempat Kerja, Jakarta : PT Gramedia Pustaka Utama

Mulyasa. 2013. Pengembangan dan Implementasi Kurikulum 2013. Bandung: PT Remaja Rosdakarya.

Raharjo Sugeng. 2003. Pengantar standar kompetensi nasional bidang gambar bangunan. Bandung.

Riana T. Mangesa. 2009. Kajian terhadap pola pendidikan berorientasi kompetensi dunia industri dalam penyiapan tenaga kerja. J. MEDTEK, Vol 12.

Satrio A. S. 2010. Pengaruh umur, pendidikan, pendapatan, pengalaman kerja dan jenis kelamin terhadap lama mencari kerja bagi tenaga kerja. Skripsi. Semarang. Fakultas Ekonomi Undip

Struyven, K., \& De Meyst, M. 2010. Competence-based teacher education: Illusion or reality? An assessment of the implementation status in Flanders from teachers' and students' points of view. Teaching and Teacher Education 26(8) 1495-1510.

https://doi.org/10.1016/j.tate.2010.05.006

Sukamto. 1988. Perencanaan \& pengembangan kurikulum pendidikan teknologi dan kejuruan. Jakarta: Departemen Pendidikan dan Kebudayaan Direktorat Jenderal Pendidikan Tinggi Proyek Pengembangan Lembaga Pendidikan Tenaga Kependidikan

Sutomo, V. Hadiwiyono dan Prihartini BS, 1999 Analisis Faktor-faktor Yang Mempengaruhi Lama Mencari Kerja Tenaga Kerja Terdidik di Kabupaten Klaten Tahun 1996 : Suatu Pendekatan Search Teori. Jurnal Perspektif No.4 Tahun 1999, Fakultas ekonomi Universitas Negeri Sebelas Maret, Surakarta. 
Suyatno. (2009). Menjelajah Pembelajaran Inovatif. Jawa Timur: Masmedi Buana Pustaka.

Thorkildsen, K., \& Råholm, M. B. 2010. The essence of professional competence experienced by Norwegian nurse students: A phenomenological study. Nurse Education in Practice 10(4) 183188.

https://doi.org/10.1016/j.nepr.2009.08.00

3) 